\title{
Relationship of acute obstructive airway change to chronic (fixed) obstruction
}

\author{
Margaret R Becklake \\ Departments of Medicine and of Epidemiology and Biostatistics \\ (Respiratory Epidemiology Unit), McGill University, Canada
}

Introductory article

\section{Cotton dust and across-shift change in $\mathrm{FEV}_{1}$ as predictors of annual change in $\mathrm{FEV}_{1}$}

\begin{abstract}
Henry W Glindmeyer, John J Lefante, Robert N Jones, Roy J Rando, Hans Weill
In this report of a 5-yr longitudinal study of workers at six cotton textile mills, exposure and acrossshift FEV 1 changes were evaluated as possible predictors of the annual change in FEV for yarn manufacturing workers. A total of 611 workers had three repeatable spirometric tests, over at least $3 \mathrm{yr}$, and at least one (average of three) across-shift test, while always working the same shift. The "same shift" criterion controlled for the effect of diurnal variation. Average exposure was determined from measures of lint-free elutriated cotton dust in combination with job histories. This study found a significant association between the acute and chronic effects of cotton dust exposure. Both exposure and across-shift change proved to be significant predictors of annual change, and excess annual declines in FEV, were predicted even for exposures of $200 \mu \mathrm{g} / \mathrm{m}^{3}$ and across-shift drops in FEV of $200 \mathrm{ml}$. These results suggest that, to prevent dust-related chronic decline in lung function, current smokers should be excluded from yarn manufacturing work and exposure should be reduced below $200 \mu \mathrm{g} / \mathrm{m}^{3}$, to approximately $100 \mu \mathrm{g} / \mathrm{m}^{3}$. (Am J Respir Crit Care Med 1994;149:584-90).
\end{abstract}

The concept that repeated acute obstructive airways responses to an occupational exposure may lead to chronic fixed airways obstruction is certainly biologically plausible. Increased airways responsiveness, which may potentiate acute obstructive changes of the airways, was listed in the 1984 Surgeon General's report on chronic obstructive lung disease ${ }^{1}$ as a putative (host) risk factor. It is also biologically plausible that repeated exposure to the putative agent will maintain an increased level of airways responsiveness in much the same way as occurs in allergic asthma with sustained exposure to the putative allergen. "Will my condition become chronic?" is one of the first questions a patient will ask, particularly if he or she perceives the symptoms of acute airways obstruction to be work-related. Whether acute and chronic airways responses which occur following a particular exposure are each related independently to the exposure, whether the first leads to the second, or whether chronic airways obstruction may arise by either route is also important in the understanding of the disease process, and ultimately in its management. Such relationships are illustrated in fig $1 .^{2}$ Finally, if chronic airways obstruction depends on repeated acute responses, across-shift changes could be used to monitor exposed populations and evaluate environmental controls.
Studies of the natural history of chronic (fixed) airways limitation - including the role, if any, of acute airways responses in its genesis - are not easy for a number of reasons. ${ }^{3-16}$ Methodological issues include how to conduct the study (design), whom to study (study population), what to measure (study outcome and exposure), and how to analyse their relationships. Cross sectional studies - the simplest and most practical - are effective in establishing prevalence of acute and chronic airways obstruction, but not their temporal and therefore potentially causal relationships. ${ }^{3}$ For this, longitudinal or cohort studies are necessary (preferably population-based rather than clinic-based), studies which are both more difficult and more expensive to carry out. When the putative exposure is occupational, the study population is usually workforce-based and, by definition, easier to identify, contact, recruit, and follow up than any community-based population sample. For studies of the natural history of chronic airways obstruction there is general agreement that the outcome measurement should be change in forced expiratory volume in one second $\left(\mathrm{FEV}_{1}\right)$ measured as $\mathrm{ml} /$ year. ${ }^{45}$ Given a within-individual variation in $\mathrm{FEV}_{1}$ measurement of the order of $200 \mathrm{ml}$ or $5 \%,{ }^{10}$ the follow up period must be of sufficient length (usually five years) 


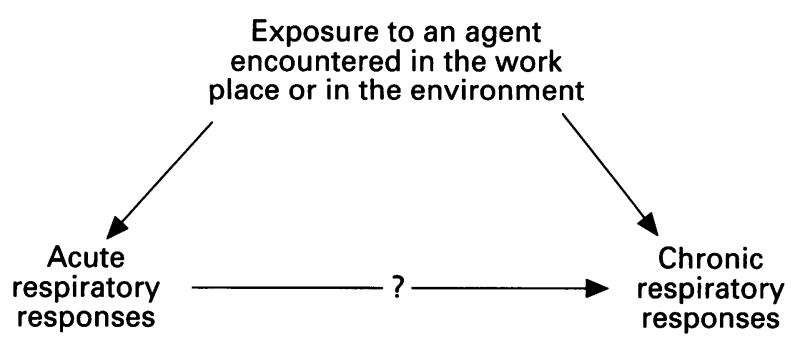

Figure 1 Relationships of acute and chronic obstructive airways responses to occupational or environmental exposure. Modified from table 2 in ref 2 and reproduced with permission.

to achieve an adequate signal/noise ratio to test the hypothesis implicit in the title of this review. Acute obstructive airways changes can be measured subjectively - for example, reported exposure-related symptoms - or objectively - for example, work-related crossshift changes in $\mathrm{FEV}_{1}$ or the magnitude of within-day variation in $\mathrm{FEV}_{1}$. Variability of $\mathrm{FEV}_{1}$ may also be measured as the response to a bronchodilator or to nonspecific challenge by methacholine or histamine.

\section{Studies in US cotton workers by Glindmeyer et $\mathrm{al}^{11}$}

The introductory article by Glindmeyer et al from Tulane University, New Orleans, ${ }^{11}$ examined the relationship between acute obstructive airway change and chronic fixed obstruction in cotton textile workers. To address this question in a population large enough, followed up long enough, with sufficient rigour, and with sufficient attention to the quality of the data gathered to be able to detect the changes sought, is a tour de force. The Tulane study exemplifies these characteristics. The objectives of the study were (1) to assess the relationship of the acute (across-shift change in lung function) and chronic (annual change in lung function) effects of cotton dust exposure, and (2) to evaluate across-shift change and dust exposure as predictors of annual changes in lung function. The data used to address these objectives were gathered during $1982-7$ as part of a routine surveillance programme conducted by a major US company in six of its cotton and three of its synthetic textile mills, ${ }^{12}$ and described in a 1991 study by Tulane researchers to investigate exposure-related declines of $\mathrm{FEV}_{1}$. As the methods and findings of the 1991 study are pertinent to the 1994 Tulane study, they will be reviewed briefly.

The outcome measurement used to describe chronic loss of function - $\mathrm{FEV}_{1}$ decline in $\mathrm{ml} /$ year $^{13}$ - was obtained from routine annual spirometric tests. Health and other information was gathered by the company using the Occupational Safety and Health Administration (OSHA) mandated questionnaire. For each subject a cumulative exposure index was calculated on job history and on annual average dust exposure. Of the 6037 textile workers originally registered in the surveillance study, $2659(44.0 \%)$ provided three spirometric testings over a period of three or more years; $2473(40.9 \%)$ had at least three trials of acceptable reproducibility at each testing, and $1817(30 \cdot 1 \%)$ had worked exclusively in either cotton yarn manufacture or cutting and slashing. The average exposure levels for airborne lint-free cotton dust to which these workers had been exposed were 0.196 and $0.455 \mathrm{mg} / \mathrm{m}^{3}$ in yarn manufacture and in slashing and weaving, respectively, levels in conformity with the OSHA permissible exposure limits of 0.20 and $0.75 \mathrm{mg} / \mathrm{m}^{3}$, respectively. Nevertheless, exposure-response relationships were shown in yarn manufacturing as well as a synergistic effect with smoking. The fact that yarn workers exhibited a greater annual decline than those in slashing and weaving despite being exposed to lower dust levels was interpreted by the authors as a dust potency effect, and may be attributable to the presence of higher endotoxin levels in the initial manufacture of yarn compared with the later processes of slashing and weaving. Endotoxin levels (currently under consideration as the bioactive agent in cotton dust ${ }^{14}$ ) were not measured and, even though dust levels remain a useful index to relate to health outcome, variation in dust:endotoxin ratios are likely in most workplaces, thus causing imprecision to the exposure measurement and attenuating estimates of association.

The 611 subjects who formed the study population for the 1994 paper $^{11}$ were selected from the 1664 yarn manufacturers who had worked only in cotton mills (36.7\% of those eligible) and had the across-shift testing done on the same shift as the data used to calculate annual decline. The analysis, stratified by shift, was based on the mean of the across-shift testings for each subject (average of three per subject). Multiple regression analyses were then carried out, controlling for age, sex, and smoking category. The results are summarised in tables 1 and 2, respectively.

The analyses directed at answering the question whether across-shift change in $\mathrm{FEV}_{1}$ was related to dust exposure level (left hand arrow, fig 1) showed that average mill exposure was a significant determinant of across-shift change for shift $1\left(-22 \cdot 2 \mathrm{ml}\right.$ per $0.10 \mathrm{mg} / \mathrm{m}^{3}$ increase in cotton dust exposure) but not for shifts 2 and 3 (table 1). The only other significant determinant of across-shift change was age $(-0.9 \mathrm{ml}$ and $-1.1 \mathrm{ml}$ additional across-shift change per year of age for workers exposed in shifts 2 and 3, respectively, but not in shift 1). Smoking was also of borderline significance for workers in shift $2(-20.4$ and $-25.5 \mathrm{ml}$ additional change for current compared to never and ex-smokers, respectively) while for those in shift 1 smoking was associated with a paradoxical increase in across-shift $\mathrm{FEV}_{1}$. These between-shift differences justified maintaining the stratification by shift for analysis of the determinants of annual change in $\mathrm{FEV}_{1}$. The analysis directed at answering the question whether the annual change in $\mathrm{FEV}_{1}$ was related to dust exposure (right hand arrow, fig 1) showed that average mill exposure was a significant independent determinant in workers in shifts 1 and $3\left(-20.3\right.$ and $-28.0 \mathrm{ml}$ per $0.10 \mathrm{mg} / \mathrm{m}^{3}$ dust exposure); a directionally similar but nonsignificant change was shown for those in shift 2 (table 1). Smoking was also a significant determinant in all three shifts, and its magnitude was comparable to that of the average mill exposure effect in shift 1 , and somewhat greater in shift 3 . The analysis examining the relationship of across-shift to annual change in $\mathrm{FEV}_{1}$ (horizontal arrow, fig 1) is shown in table 2. For all three shifts, across-shift change was a significant determinant of annual change. However, for shift 1, but 


\begin{tabular}{|c|c|c|c|c|c|c|}
\hline \multirow{3}{*}{ Determinants } & \multicolumn{6}{|c|}{ Regression coefficients for across-shift and annual FEV, changes } \\
\hline & \multicolumn{3}{|c|}{ Across-shift change } & \multicolumn{3}{|c|}{ Annual change } \\
\hline & Shift 1 & Shift 2 & Shift 3 & Shift 1 & Shift 2 & Shift 3 \\
\hline $\begin{array}{l}\text { Sex } \\
\text { Men } v \text { women }\end{array}$ & $14 \cdot 3$ & $-14 \cdot 1$ & $3 \cdot 2$ & -6.9 & $-14 \cdot 2$ & $-10 \cdot 3$ \\
\hline $\begin{array}{l}\text { Smoking } \\
\text { Current v never } \\
\text { Current } v \text { ex-smoker } \\
\text { Ex-smoker } v \text { never }\end{array}$ & $\begin{array}{r}19 \cdot 6 \\
6 \cdot 3 \\
13 \cdot 3\end{array}$ & $\begin{array}{r}-20.4 \\
-25.5 \\
5.1\end{array}$ & $\begin{array}{r}-10.4 \\
-6 \cdot 3 \\
-4 \cdot 1\end{array}$ & $\begin{array}{c}-19.1^{*} \\
-18.4^{*} \\
-0.7\end{array}$ & $\begin{array}{c}-21.5^{*} \\
-5.0 \\
-16.5\end{array}$ & $\begin{array}{l}-36.7^{*} \\
-25 \cdot 6^{*} \\
-10.9\end{array}$ \\
\hline Age per year & -0.3 & $-0.9 *$ & $-1 \cdot 1 *$ & 0.1 & -0.1 & -0.7 \\
\hline $\begin{array}{l}\text { Average mill exposure } \\
\text { per } 0.10 \mathrm{mg} / \mathrm{m}^{3}\end{array}$ & $-22 \cdot 2^{*}$ & -7.0 & $2 \cdot 2$ & $-20 \cdot 3^{*}$ & $-10 \cdot 3$ & $-28.0^{*}$ \\
\hline
\end{tabular}

Source: Glindmeyer et al." These data were derived from a multiple regression analysis which included all the determinants listed. The analysis therefore reflects the independent relationships of across-shift and annual FEV 1 change to each determinant after taking the others into account, and the regression coefficients indicate the amount and direction of additional across-shift or annual FEV, change attributable to account, and the reterminant. each deter 0.05 .

not for shifts 2 and 3, part of the across-shift effects was attributable to average mill exposure (see footnote to table 2).

In their discussion the authors acknowledge that their conclusions are based on a small subset of workers but point out that the selection did not produce any obvious bias in terms of age, duration of employment, baseline $\mathrm{FEV}_{1}$, smoking, gender and race, or percentage prevalence of symptoms. An important proportion of loss to follow up was due to a contraction of the workforce for economic reasons. In addition, the between-shift differences both for across-shift and for annual changes in $\mathrm{FEV}_{1}$ suggested to the authors the presence of unrecognised, unmeasured factors - host and environmental - influencing the lung responses. In their abstract the authors conclude that (1) both average

Table 2 Determinants of chronic change (annual FEV, change in mllyear) in 611 cotton textile workers in yarn manufacturing

\begin{tabular}{|c|c|c|c|}
\hline \multirow[b]{2}{*}{ Determinant } & \multicolumn{3}{|c|}{$\begin{array}{l}\text { Regression coefficient for } \\
\text { annual FEV, change }\end{array}$} \\
\hline & $\begin{array}{l}\text { Shift } 1 \\
(n=346)\end{array}$ & $\begin{array}{l}\text { Shift } 2 \\
(n=128)\end{array}$ & $\begin{array}{l}\text { Shift } 3 \\
(n=137)\end{array}$ \\
\hline $\begin{array}{l}\text { Sex } \\
\text { Men } v \text { women }\end{array}$ & $-7 \cdot 7$ & -11.8 & $-10 \cdot 9$ \\
\hline $\begin{array}{l}\text { Smoking } \\
\text { Current } v \text { never } \\
\text { Current } v \text { ex-smoker } \\
\text { Ex-smoker } v \text { never }\end{array}$ & $\begin{array}{c}-20 \cdot 2^{*} \\
-18.7^{*} \\
-1.4\end{array}$ & $\begin{array}{c}-18.1^{*} \\
-0.7 \\
-17.4\end{array}$ & $\begin{array}{l}-34 \cdot 9^{*} \\
-24 \cdot 7 \\
-10 \cdot 2\end{array}$ \\
\hline Age per year & 0.1 & 0.0 & -0.5 \\
\hline $\begin{array}{l}\text { Average mill exposure } \\
\text { per } 0.10 \mathrm{mg} / \mathrm{m}^{3}\end{array}$ & $-19 \cdot 1^{*}$ & $-9 \cdot 1$ & $-28 \cdot 3^{*}$ \\
\hline $\begin{array}{l}\text { Across-shift decline in FEV } \\
\text { per } 200 \mathrm{ml}\end{array}$ & $-11 \cdot 2^{*}$ & $-33 \cdot 5^{*}$ & $-36 \cdot 0^{*}$ \\
\hline \multicolumn{4}{|c|}{$\begin{array}{l}\text { Source: Glindmeyer et al. }{ }^{11} \text { The table shows regression coefficients } \\
\text { which indicate the amount and direction of annual FEV } \text { change } \\
\text { by category of determinant. Note that for shift } 1 \text {, across-shift } \\
\text { change was confounded by average mill exposure (the regression } \\
\text { coefficient decreased from }-15.9 \text { to }-11.2 \text { when average mill } \\
\text { exposure was added to the model), in contrast to shifts } 2 \text { and } 3 \\
\text { for which comparable coefficients were }-34.6 \text { and }-33.5 \text {, and } \\
-35.4 \text { and }-36.0 \text {, respectively. } \\
{ }^{*} p<0.05 \text {. }\end{array}$} \\
\hline
\end{tabular}

mill exposure and across-shift changes are predictors of annual change in $\mathrm{FEV}_{1}$; (2) these effects are seen even for exposures in the neighbourhood of the current OSHA permissible exposure limits of $0.2 \mathrm{mg} / \mathrm{m}^{3}$ and for modest across-shift falls in $\mathrm{FEV}_{1}$ of $200 \mathrm{ml}$; and (3) given the synergistic effect between cotton dust exposure and smoking on annual decline in $\mathrm{FEV}_{1}$, smokers should be excluded from the workforce and dust levels reduced to $0.1 \mathrm{mg} / \mathrm{m}^{3}$ to prevent the dust-related annual decline in $\mathrm{FEV}_{1}$ in cotton yarn manufacturers.

The strengths of the study include its cohort design, the large source population, and the attention to quality control. Its weaknesses include the fact that the study inferences are based on only $36 \cdot 7 \%(611 / 1664)$ of eligible textile workers. The inconsistency of findings between shifts may reflect the strength of the circadian effects on $\mathrm{FEV}_{1}$, making stratification by shift a reasonable approach to control for confounding owing to this powerful biological effect. This, in turn, reduced the number of study subjects in each group, and hence study power. Provided it was random in relation to exposure, selection bias due to loss to ill health and exclusion of those with non-repeatable spirometric tests would have led to attenuation (not exaggeration) of the relationships on which the study inferences are based. ${ }^{18}$ In addition, across-shift changes may have been underestimated for some subjects studied during rather than at the beginning of the follow up period, since it is at least biologically plausible that across-shift changes may become less marked as airways limitation becomes more firmly established. In summary, the threats to study inferences from selection bias and potential confounding by other workplace contaminants are more likely to have attenuated than exaggerated the study relationships on which the study inferences are based.

The finding by the Tulane investigators of a significant association between the acute (across-shift) and chronic effects of cotton dust exposure directly addresses the topic of this review, and supports the concept that recurrent acute obstructive airway changes lead to chronic (fixed) airways obstruction. Since the results were not entirely consistent between shift, more than one pathophysiological mechanism may be involved. In 


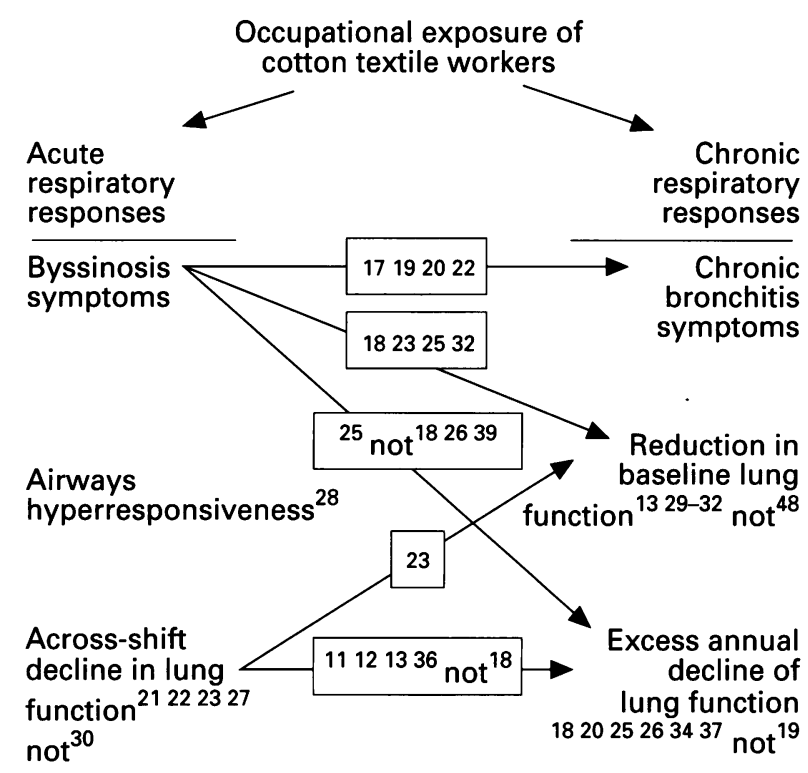

Figure 2 Relationships of acute and chronic respiratory responses of cotton textile workers to their occupational exposure. Modified from table 3 (in ref 2) and reproduced with permission. The references which provide evidence for and against the associations indicated by the arrows are shown.

shift 1, for example, part of the chronic effect appeared to be a direct result of exposure. A common final pathway for both direct and indirect effects may be chronic airways inflammation (see below).

\section{Cotton and other occupational dusts}

The framework illustrated in fig 1 was used in an earlier 1988 review $^{2}$ to summarise the evidence that exposure to cotton dust causes acute and chronic respiratory responses and their interrelationships. ${ }^{17-27}$ This review has been updated in fig 2 to include pertinent information published since $1988 .^{28-39}$

The evidence that occupational exposure of cotton textile workers causes chronic (fixed) airways obstruction had long been considered controversial; ${ }^{215}$ it was certainly considered controversial when the Tulane studies were undertaken in the mid-1980s. The findings from these studies ${ }^{11-13}$ add considerable strength to the evidence that this association is causal by providing, for the first time, data on objectively measured exposureresponse relationships within an exposed population, as opposed to evidence based on a comparison of exposed versus non-exposed populations. Included in fig 2 are the results of another cohort study, also published in 1994, which used similar methodology to the Tulane studies but in a different population - cotton textile workers in Shanghai, China. ${ }^{3637}$ Though average dust levels were higher, the results were similar to those obtained in the Tulane studies. Thus, the Shanghai studies found that, compared with silk workers, cotton workers more frequently exhibited across-shift changes, their average annual decline was greater, and acrossshift change predicted chronic fixed airways obstruction. However, unlike the Tulane studies, when exposureresponse analyses were carried out, the Shanghai study (like many others) was unable to show any exposure- related variation in symptoms, lung function level, or longitudinal change in lung function.

The fact that exposure-response relationships have not been consistently demonstrable, despite much effort and high technology having been expended on measuring dust levels, ${ }^{11-13183637}$ is certainly consistent with the view that the agent responsible for the acute and chronic changes following exposure to cotton dust is not the cotton dust itself but some related agent such as endotoxin levels. The underlying mechanisms by which endotoxin might work are currently attracting research attention. ${ }^{40}$

If the evidence that acute (across-shift) obstructive airway changes are predictors of subsequent chronic (fixed) airways obstruction was confined to cotton dust, then the implications would be limited to identifying the causal agent(s) in cotton dust and its public health control. However, several other occupational exposures have been investigated in a similar way and, for some, similar relationships have been found. ${ }^{2}$ Most coherent is the evidence for another plant dust, grain, summarised in fig $3 .^{41-54}$ Not only is the evidence linking acute respiratory responses with exposure strong, and almost as strong for annual decline in lung function, but also (and in contrast to cotton dust) exposure measured in $\mathrm{mg} / \mathrm{m}^{3}$ was consistently related to cross sectional and longitudinal lung function outcomes for the workforce which furnished most of the data in fig 3 - namely, elevator workers in the port of Vancouver. ${ }^{4344}$ 47-52 This suggests that the exposure measurements used in these studies correctly reflect the biological potency of the dust in question. Of particular interest in the grain studies is the consistency across studies of the association (and predictive value) of across-shift and across-week changes to annual changes in lung function. Evidence of similar effects due to exposure to other plant dusts such as western red cedar and coffee bean dust is less consistent but suggestive. ${ }^{2}$ The same is true for exposure to various chemicals encountered in the workplace such as isocyanates, irritant gases, and inorganic dusts. ${ }^{25-57}$

\section{The natural history of chronic (fixed) airways obstruction}

Can the concepts embodied in figs 1-3 be accommodated into what is known about the natural history of chronic obstructive pulmonary disease (COPD)? In the 1960s two different hypotheses of the natural history of COPD were proposed based on two cohort studies, one carried out in the $\mathrm{UK}^{4}$ and one in the Netherlands. ${ }^{5}$ The objective of the UK study was to investigate chronic bronchitis, then considered a British disease and thought to be due to recurrent infections brought on by the damp British climate and heavy urban air pollution. The study was workforcebased, and questionnaire and lung function data were gathered at six monthly intervals over a seven year period in almost 800 men aged 30-55 recruited from transport and service industries in West London and employed in non-dusty occupations. The results suggested that the main determinant of chronic airways obstruction was not infective but environmental, in the form of exposure to tobacco smoke, and this led to two separate conditions - bronchitis with mucus hypersecretion which was reversible when exposure ceased, 


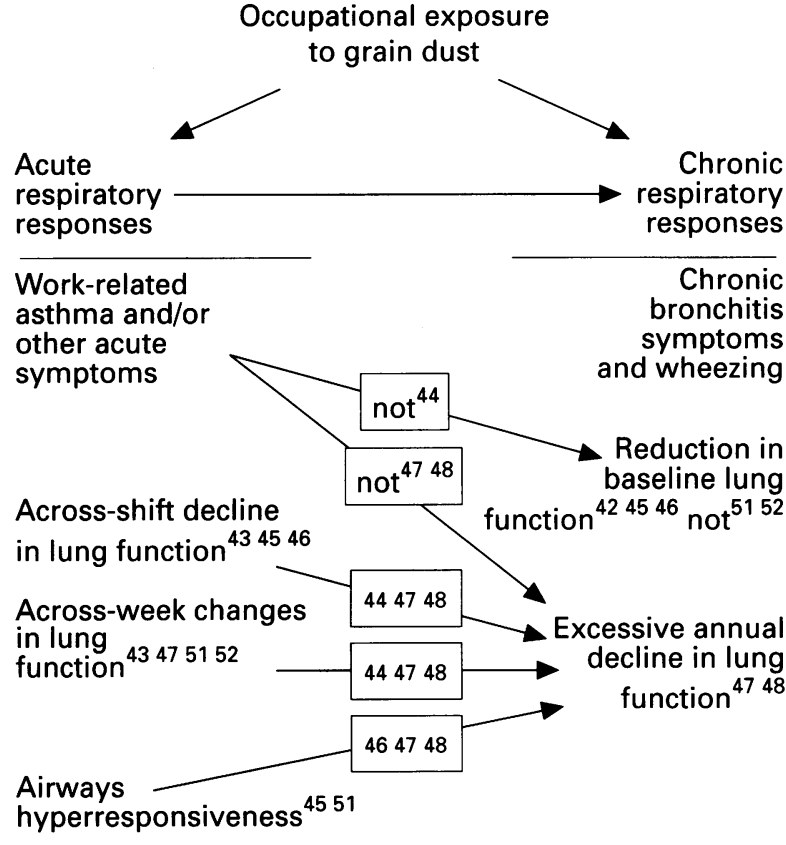

Figure 3 Relationships between acute and chronic respiratory responses to occupational exposure to grain dust. Modified from table 4 in ref 2 and reproduced with permission.

and chronic airflow limitation which was not. Both could also occur together. Asthma, defined as reversible airflow limitation, was considered to be a separate and unrelated condition. The Dutch study was communitybased and data were gathered on over 4500 men and women of all ages including adolescents from three regions of the country - one rural, one urban, and one urban industrial. The results, while supporting the concept that chronic bronchitis and chronic airflow limitation were independent processes, suggested that the main determinant of both was not environmental but a host factor characterised as an asthmatic tendency. Follow up observations on both study populations yielded evidence in favour of the other hypothesis, and current views incorporate both. ${ }^{6}$

Dutch researchers recently reviewed their hypothesis for its relevance in the 1990s and reaffirmed the concept that asthma, chronic bronchitis, and emphysema should be considered different manifestations of one disease entity in which host and environmental factors both play a part. ${ }^{5}$ They postulate separately inherited tendencies to develop allergic sensitisation and bronchial hyperresponsiveness as important denominators of disease susceptibility. In response to environmental exposure to allergens or irritants, inflammatory airways reactions develop leading to bronchial obstruction. Childhood complications and co-existing lung disease in later life, together with smoking, converge to determine the phenotype patient. Though not mentioned, occupational exposures could be accommodated in the same way as smoking. For instance, (1) acute airways responses to cotton dust exposure may be mediated through allergic and/or non-allergic mechanisms, depending on the inherited characteristics of the individual exposed; (2) inherited characteristics may also explain the between-individual differences in response to what appears to be the same level and dose of exposure; (3) both mechanisms appear to act through a common pathway leading to chronic airways inflammation sustained by continued exposure; (4) smoking effects may be additive or synergistic with other exposures to maintain the chronic inflammatory process; and (5) the removal from exposure may not necessarily reverse the inflammatory process.

The relationships implicit in the horizontal arrow in figs 1-3 (whether acute changes predict chronic changes) have been much less consistently examined than the relationship implicit in the right and left facing arrows (whether acute and chronic changes are doserelated to exposure), although there must be many data sets available in which these relationships could be examined. In addition, only in the Tulane studies in which exposure-response relationships were demonstrable for acute responses was it possible to examine whether acute changes were in the causal pathway for, or independently related to, chronic changes. For all shifts acute responses predicted annual changes, though for shift 1 (but not shifts 2 and 3) the relationship was confounded by exposure dose. The authors put weight on the shift 1 findings because of the larger numbers and because confounding bias due to circadian changes was judged to be less important in shift 1 than in shifts

\section{LEARNING POINTS}

* Cotton dust exposure may cause both acute obstructive airways changes and chronic fixed obstruction (COPD).

* Acute obstructive responses to cotton dust may predict chronic obstructive responses.

* There is some uncertainty as to whether the acute responses are always in the causal pathway for chronic responses or are independently related to exposure, or whether both mechanisms operate.

* Similar findings for exposure to grain dust imply a much broader role for occupational exposures in the genesis of COPD than is usually envisaged.

* Host factors probably play an additional part in the genesis of chronic airways obstruction (Dutch hypothesis). 
2 and 3. If this is so, then the results for cotton dust suggest that more than one mechanism may be operating to produce the acute responses, a dose-related mechanism acting through an irritant process and a non-dose related mechanism possibly acting through an allergic process. This concept is certainly consistent with the Dutch hypothesis that there are separate inherited tendencies which determine whether an individual will exhibit allergic and/or irritant responses to airborne exposures. An alternative and plausible explanation, and one for which there is some evidence, is that the exposure measurement chosen does not correctly reflect the bioactivity of the dust. With regard to the data on grain dust which do show a relationship between acute cross-shift changes and exposure dose in one case control study, ${ }^{48}$ these have not been analysed to address the question whether acute changes are in the causal pathway leading to chronic fixed airflow limitation or are independently related to exposure.

1 US Department of Health and Human Services. The health consequences of smoking. Chronic obstructive lung disease: a report of the Surgeon
General. US Department of Health and Human Services, Public Health Service, Office on Smoking and Health, DHSS Publication Health Service, Office on Smoking
No. (PHS) 84-50205, 1984:568.

2 Becklake MR, Bourbeau J, Menzies R, Ernst P. The relationship between acute and chronic airway responses to occupational exposure. In: Simmons DH, ed. Current pulmonology. Chicago: Year Book Medical Publishers, 1988:25-66. 3 Schilling R. Worldwide problems of byssinosis. Chest 1981;79(Suppl):

4 Fletcher C, Peto R, Tinker C, Speizer FE. The natural history of chronic bronchitis and emphysema. Oxford: Oxford University Press, 1976:271.

5 Sluiter HJ, Koëter GH, de Monchy JGR, Postma DS, de Vries K, Orie NGM. The Dutch hypothesis (chronic nonspecific lung disease) revisited. Eur Respir f 1992;4:479-89.

6 Becklake MR. Occupational exposures and chronic airways disease. In: Rom WN, ed. Environmental and occupational medicine. 2nd edn. Toronto: Little, Brown, 1992:453-63.

7 Samet JM. Definitions and methodology in COPD research. In: Hensley MJ, Saunders NA, eds. Clinical epidemiology of chronic obstructive pulmonary disease. New York: Marcel Dekker, 1989:1-22.

8 Glindmeyer HW, Jones RN, Diem JE, Weill H. Useful and extraneous variability in longitudinal assessment of lung function. Chest 1987;92: 877-82.

9 Hill AB. The environment and disease: association or causation? Proc $R$ Soc Med 1965;58:7-12.

10 Becklake MR, White N. Sources of variation in spirometric measurements: identifying the signal and dealing with noise. Occup Med 1993;8:241-64

11 Glindmeyer HW, Lefante JJ, Jones RN, Rando RJ, Weill H. Cotton dust and across-shift change in FEV 1 as predictors of annual change in $\mathrm{FEV}_{1}$. Am $\mathcal{F}$ Respir Crit Care Med 1994;149:584-90

12 Glindmeyer HW, Lefante JJ, Jones RN, Rando RJ, Kader HMA, Weill $\mathrm{H}$. Exposure-related declines in the lung function of cotton textile workers. Relationship to current workplace standards. Am Rev Respir Dis 1991;144:675-83.

13 Glindmeyer $\mathrm{H}$, Lefante J, Jones $\mathrm{R}$, Weill $\mathrm{H}$. FEV $\mathrm{F}_{1}$ annual change: effect of excluding non-repeatable data. Am Rev Respir Dis 1990;141:A328.

14 Castellan RM, Olenchock SA, Kinsley KB, Hankinson JL. Inhaled endotoxin and decreased spirometric values. An exposure-response relation for cotton dust. $N$ Engl $\mathcal{F}$ Med 1987;317:605-10.

15 Weill H. Problem solving in occupational airway disorders. Chest 1981; 49(Suppl): 1-2S

16 Becklake MR, Lalloo UG. The "healthy smoker": a phenomenon of health selection? Respiration 1990;57:137-44.

17 Molyneux MKB, Tombleson JBL. An epidemiological study of respiratory symp

18 Berry G, McKerrow CB, Molyneux MKB, Rossiter CE, Tombleson JBL. A study of the acute and chronic changes in ventilatory capacity $\mathrm{JBL}$. A study of the acute and chronic changes in ventilatory capacity
of workers in Lancashire cotton mills. Br f Ind Med 1973;30:25-36.

19 Berry G, Molyneux MKB, Tombleson JBL. Relationships between dust levels and byssinosis and bronchitis in Lancashire cotton mills. $\mathrm{Br} \mathcal{F}$ Ind Med 1974;31:18-27.

20 Fox AJ, Tombleson JBC, Watt A, Wilkie AG. A survey of respiratory disease in cotton operatives. Part I. Br f Ind Med 1973;30:42-7.

21 Merchant JA, Kilburn KH, O'Fallon WM, Hamilton JD, Lumsden JC. Byssinosis and chronic bronchitis among cotton textile workers. Ann Intern Med 1972;76:423-33.

22 Merchant JA, Lumsden JC, Kilburn KH, O'Fallon WM, Ujda JR, Germino VH, et al. An industrial study of the biological effects of cotton 121

23 Imbus HR, Suh MW. Byssinosis. Arch Environ Health 1973;26:183-91.

24 Jones RN, Diem JE, Glindmeyer H, Dharmanajan V, Hammad YY,
Carr J, et al. Mill effect and dose-response relationships in byssinosis. Br $\mathcal{F}$ Ind Med 1979;36:305-13.

25 Kamat SR, Kamat GR, Salpeker H, Lobo E. Distinguishing byssinosis from chronic obstructive pulmonary disease. Am Rev Respir Dis 1981; 124:31-40.

26 Beck GJ, Schacter EN, Maunder LR, Schilling RSF. A prospective study of chronic lung disease in cotton textile workers. Ann Intern Med 1982;97:645-51.

27 Elwood JH, Elwood PC, Campbell MJ, Stanford CF, Chivers A, Hey I, et al. Respiratory disability in oxflax workers. $\mathrm{Br}$ F Ind Med 1986; 43:300-6.

28 Fishwick D, Fletcher AM, Pickering CA, Niven RM, Faragher EB. Lung function, bronchial reactivity, atopic status and dust exposure in Lancashire cotton mill operatives. Am Rev Respir Dis 1992;145: 1103-8.

29 Fishwick D, Fletcher AM, Pickering CA, Niven RM, Faragher EB Respiratory symptoms and dust exposure in Lancashire cotton and man-made fibre mill operatives. Am $\mathcal{F}$ Respir Crit Care Med 1994;150 441-7.

30 Massin N, Moulin JJ, Wild P, Meyer-Bisch C, Mur JM. A study of the prevalence of acute respiratory disorders among workers in the textile industry. Int Arch Occup Environ Health 1991;62:555-60.

31 Waldeyohannes M, Bergevin Y, Mgeni AY, Thériault G. Respiratory problems among cotton textile workers in Ethiopia. Br $\mathcal{f}$ Ind Med problems among

32 Velazques AM, Christiani DC, McConnell R, Eisen EA, Wilcox M. Respiratory disease in a textile factory in Nicaragua. $A m \mathcal{F}$ Ind $\mathrm{Med}$ 1991;20:195-208.

33 Beckett WB, Pope CA, Xu Xp, Christiani D. Women's respiratory health in the cotton textile industry: an analysis of respiratory symptoms in 973 non-smoking female workers. Occup Environ Med 1994;51:14-8.

34 Zuskin E, Ivankovic D, Schachter EN, Witek TJ. A ten-year follow-up study of cotton textile workers. Am Rev Respir Dis 1991;143:301-5.

35 Mathur N, Gupta BN, Rastugi SK. Multivariate analysis of byssinosis risk assessment. Indian $\mathcal{f}$ Chest Dis Allied Sci 1993;35:185-90.

36 Christiani DC, Wegman DH, Eisen EA, Ye T-T, Lu P-L, Olenchock SA. Cotton dust and Gram-negative bacterial endotoxin correlations in two cotton textile mills. Am F Ind Med 1993;23:333-42.

37 Christiani DC, Ye T-T, Wegman DH, Eisen EA, Dai, H-L, Lu P-L. Cotton dust exposure, across-shift drop in $\mathrm{FEV}_{1}$, and five-year change in lung function. Am $\mathcal{F}$ Respir Crit Care Med 1994;150:1250-5.

38 Sigsgaard T, Pedersen OF, Juul S, Gravesen S. Respiratory disorders and atopy in cotton wool, and other textile mill workers in Denmark. Am 于 Ind Med 1992;22:163-84.

39 Larson RK, Barman ML. A longitudinal study of pulmonary function in cotton gin workers in the San Joaquin Valley. Chest 1989;96:819-23.

40 De Lucca AJ, Brogden KA, Catalano EA, Morris NM. Biophysical alteration of lung surfactant by extracts of cotton dust. $B r F$ Ind Med 1991;48:41-7.

41 Chan-Yeung M, Enarson DA, Kennedy SM. The impact of grain dust on respiratory health. Am Rev Respir Dis 1992;145:476-87.

42 Dosman JA, Cotton DJ, Graham BL, Li KYR, Froh F, Barnett GD. Chronic bronchitis and decreased forced expiratory flow rates in lifetime nonsmoking grain workers. Am Rev Respir Dis 1980;121:11-6.

43 Chan-Yeung M, Schulzer M, Maclean L, Dorken E, Grzybowski S. Epidemiologic health survey of grain elevator workers in British Columbia. Am Rev Respir Dis 1980;121:329-38.

44 Chan-Yeung M, Schulzer M, Maclean L, Dorken E, Tan F, Lam S. A follow-up study of the grain elevator workers in the port of Vancouver. Arch Environ Health 1981;36:75-81.

45 Corey P, Hutcheon M, Broder I, Mintz S. Grain elevator workers show work-related pulmonary function changes and dose-effect relationships with dust exposure. Br $\mathcal{F}$ Ind Med 1982;39:330-7.

46 doPico G, Reddan W, Anderson S, Flaherty D, Smalley E. Acute effects of grain dust exposure during a work shift. Am $\mathcal{f}$ Respir Dis 1983;128: 399-404.

47 Tabona M, Chan-Yeung M, Enarson D, Maclean L, Dorken E, Schulzer M. Host factors affecting longitudinal decline in lung spirometry among grain elevator workers. Chest 1984;85:782-6.

48 Enarson DA, Vedal S, Chan-Yeung $M$. Rapid decline in $\mathrm{FEV}_{1}$ in grain handlers. Am Rev Respir Dis 1985;132:814-7.

49 Enarson DA, Chan-Yeung $M$, Tabona M, Kus J, Vedal S, Lam S. Predictors of bronchial hyperexcitability in grain handlers. Chest 1985 ; 87:452-5.

50 Chan-Yeung M, Vedal S, Lam S, Enarson D. Immediate skin reactivity and its relationship to age, sex, smoking and occupational exposures. Arch Environ Health 1985;40:53-7.

51 Yach D, Myers J, Bradshaw D, Benatar SR. A respiratory epidemiologic survey of grain mill workers in Cape Town, South Africa. Am Rev Respir Dis 1985;131:505-10.

52 Chan-Yeung M, Dimich-Ward H, Enarson DA, Kennedy SM. Five cross-sectional studies in grain elevator workers. Am $\mathcal{F}$ Epidemiol 1992; 136:1269-79

53 Fonn S, Becklake MR. Documentation of ill health effects of occupational exposure to grain dust through sequential coherent epidemiologic investigation. Scand $\mathcal{f}$ Work Environ Health 1994;20:13-21

54 Huy T, de Schiffer K, Chan-Yeung M, Kennedy S. Grain dust and lung function: dose response relationships. Am Rev Respir Dis 1991; 144:1314-21.

55 Cotes JE, Feinmann EL, Male VJ, Rennie FS, Wickham CAC. Respiratory symptoms and impairment in shipyard welders and caulker/ burners. Br ₹ Ind Med 1989;46:292-301.

56 Chinn DJ, Stevenson IC, Cotes JE. Longitudinal respiratory survey of shipyard workers: 'effects of trade and atopic status. $\mathrm{Br} \mathcal{F}$ Ind Med 1990;47:83-90.

57 Cowie RL. Pulmonary dysfunction in gold miners with reactive airways. Br $\mathcal{F}$ Ind Med 1989;46:873-6. 